\title{
A New Perspective on Fluorapatite Dissolution in Hydrochloric Acid: Thermodynamic Calculations and Experimental Study
}

\author{
Kaia Tõnsuaadu*, Juha Kallas, Rein Kuusik, Gizem Hacialioglu-Erlenheim and Andres Trikkel *D
}

Citation: Tõnsuaadu, K.; Kallas, J.; Kuusik, R.; Hacialioglu-Erlenheim, G.; Trikkel, A. A New Perspective on Fluorapatite Dissolution in Hydrochloric Acid: Thermodynamic Calculations and Experimental Study. Inorganics 2021, 9, 65. https:// doi.org/10.3390/inorganics 9080065

Academic Editor: Duncan H. Gregory

Received: 16 June 2021

Accepted: 5 August 2021

Published: 16 August 2021

Publisher's Note: MDPI stays neutral with regard to jurisdictional claims in published maps and institutional affiliations.

Copyright: (c) 2021 by the authors. Licensee MDPI, Basel, Switzerland. This article is an open access article distributed under the terms and conditions of the Creative Commons Attribution (CC BY) license (https:// creativecommons.org/licenses/by/ $4.0 /)$.
Department of Materials and Environmental Technology, Tallinn University of Technology, 19086 Tallinn, Estonia; juha.kallas@taltech.ee (J.K.); rein.kuusik@taltech.ee (R.K.); gizem.hacialioglu-erlenheim@taltech.ee (G.H.-E.)

* Correspondence: kaia.tonsuaadu@taltech.ee (K.T.); andres.trikkel@taltech.ee (A.T.)

\begin{abstract}
Apatite (Ap) dissolution in diluted acids is well described in the literature, but in technological processes which use more concentrated acids, the reaction is fast, and it is complicated to follow the process kinetics. The relationship between $\mathrm{pH}$ change and the apatite dissolution rate depending on $\mathrm{HCl}$ concentration was studied by thermodynamic calculations and experiments with synthetic fluorapatite (FAp). On the basis of experimental $\mathrm{pH}$ measurements, the kinetics of dissolution was analyzed. The solution composition $(\mathrm{P}, \mathrm{Ca}, \mathrm{F})$ was determined by wet chemical methods and the solid part was characterized by XRD and FTIR. It was shown that the amount of $\mathrm{HCl}$ needed for FAp dissolution depends on acid concentration. FAp dissolution rate cannot be deduced from solubility data of $\mathrm{P}, \mathrm{Ca}$ or $\mathrm{F}$ as the secondary reactions of $\mathrm{CaF}_{2}$ and $\mathrm{CaHPO}_{4}$ formation take place simultaneously. It was found that the Ap dissolution rate can be followed by $\mathrm{pH}$ change.
\end{abstract}

Keywords: apatite dissolution; dissolution kinetics; fluorapatite; thermodynamic calculations

\section{Introduction}

The main source of phosphorus for mankind is natural apatites. The biggest part of natural calciumfluorapatite (CaFAp) is used for the production of phosphorus fertilizers and phosphoric acid via acidic digestion processes [1].

The studies of CaAp dissolution processes in acids have been comprehensively reviewed by Dorozkin up to the year 2010, and a general description of the dissolution stages has been given [2]. The dissolution of apatite is described by different models: a diffusion and kinetical model, a mono- and poly-nuclear model, a self-inhibition model, a stoichiometric/non-stoichiometric dissolution, an ion-exchange model, a hydrogen catalytic model, and an etch pit formation model, which all depend on the experiment conditions and sample composition. Most of the models have been elaborated for apatite dissolution in either slightly acidic or nearly neutral $(4<\mathrm{pH}<8)$ aqueous solutions and at relatively low concentrations. Therefore, the validity of these models for apatite dissolution in strong acids $\left(\mathrm{HCl}, \mathrm{HNO}_{3}, \mathrm{H}_{2} \mathrm{SO}_{4}\right)$ at $\mathrm{pH}<2$ used in the production of fertilizers and phosphorus acid as well as in the recovery technologies of rare earth elements needs specification.

The chemical model developed for the description of Ap dissolution in strong acidic media based on indirect measurements describes the dissolution of Ap as follows [2]:

$$
\begin{gathered}
\mathrm{Ca}_{5}\left(\mathrm{PO}_{4}\right)_{3}(\mathrm{~F}, \mathrm{OH})+\mathrm{H}_{2} \mathrm{O}+\mathrm{H}^{+} \rightarrow \mathrm{Ca}_{5}\left(\mathrm{PO}_{4}\right)_{3}\left(\mathrm{H}_{2} \mathrm{O}\right)^{+}+\mathrm{HF}, \mathrm{H}_{2} \mathrm{O} \\
2 \mathrm{Ca}_{5}\left(\mathrm{PO}_{4}\right)_{3}\left(\mathrm{H}_{2} \mathrm{O}\right)^{+} \rightarrow 3 \mathrm{Ca}_{3}\left(\mathrm{PO}_{4}\right)_{2}+\mathrm{Ca}^{2+}+2 \mathrm{H}_{2} \mathrm{O} \\
\mathrm{Ca}_{3}\left(\mathrm{PO}_{4}\right)_{2}+2 \mathrm{H}^{+} \rightarrow \mathrm{Ca}^{2+}+2 \mathrm{CaHPO}_{4} \\
\mathrm{CaHPO}_{4}+\mathrm{H}^{+} \rightarrow \mathrm{Ca}^{2+}+\mathrm{H}_{2} \mathrm{PO}_{4}^{-}
\end{gathered}
$$

Net-reaction $5 \mathrm{Ca}^{2+}+3 \mathrm{PO}_{4}{ }^{3-}+\mathrm{F}^{-}, \mathrm{OH}^{-}+7 \mathrm{H}^{+} \rightarrow 5 \mathrm{Ca}^{2+}+3 \mathrm{H}_{2} \mathrm{PO}_{4}{ }^{-}+\mathrm{HF}_{2} \mathrm{H}_{2} \mathrm{O}$ 
According to this model, chemical dissolution of apatite occurs step by step on the surface via intermediate formation of a monoatomic layer of some virtual compounds, like $\mathrm{Ca}_{3}\left(\mathrm{PO}_{4}\right)_{2}$ and $\mathrm{CaHPO}_{4}$.

In the latest studies of the dissolution of various natural [3-7] and some synthetic carbonate apatites $[8,9]$ using chemical and thermochemical methods, the main controlling factors discussed are the acid concentration, apatite particle size, time, and solid/liquid ratio. The amounts of $\mathrm{HCl}$ used in these experiments have been much higher than needed in a stoichiometric reaction. However, the conclusion has been made that the rapid leaching of $\mathrm{Ca}, \mathrm{P}$, and $\mathrm{F}$ in strong acid solutions of high concentration (up to $1 \mathrm{M}$ ) in a short time interval of 10-30 min is problematic for proper investigation of kinetics and detailed reaction mechanism $[7,10]$.

The thermochemical method used for the study of kinetics of FAp dissolution in $\mathrm{HCl}$ at the concentration of 1-2 $\mathrm{M}$ and acid dose 28 mole $\mathrm{HCl}$ per 1 mole of FAp revealed a very fast reaction, which is affected by apatite composition [9]. The reaction of apatite decomposition is generally described by the following equation

$$
\mathrm{Ca}_{5}\left(\mathrm{PO}_{4}\right)_{3} \mathrm{~F}+10 \mathrm{H}^{+}+10 \mathrm{Cl}^{-} \rightarrow 5 \mathrm{Ca}^{2+}+3 \mathrm{H}_{3} \mathrm{PO}_{4}+10 \mathrm{Cl}^{-}+\mathrm{HF}
$$

Based on the activation energies, the dissolution mechanism of $\mathrm{Ca}$ and $\mathrm{P}$ in $\mathrm{HCl}$ is stated to be mainly controlled by chemical kinetics $[9,11]$. However, a conclusion that the dissolution is limited by the product layer diffusion process [12] has also been made. In addition, the counteraction of the reaction products of apatite dissolution in technological processes at these relatively high saturation conditions should be considered as well.

Thus, there is no clear understanding of how to describe the rate of apatite dissolution at its initial stage in strong acid solutions of high concentrations.

The aim of this study was to find dependence between $\mathrm{pH}$ change and the apatite dissolution rate in fluorapatite dissolution reactions by thermodynamic calculations and experiments with synthetic flourapatite at near-stoichiometric conditions in hydrochloric acid media.

\section{Results and Discussion}

\subsection{Thermodynamic Calculations}

The thermodynamic calculations $(\mathrm{HsC})$ were performed for $\mathrm{HCl}$ solutions with concentrations from 0.05 to $2 \mathrm{M}$ adding FAp by the step of $0.02 \mathrm{~mol}$ and with different compositions of the solid phase formed in the reaction: $\mathrm{HsC1}$ - with the formation of $\mathrm{CaF}_{2}$, and $\mathrm{HsC2}-$ with the formation of $\mathrm{CaF}_{2}$, together with $\mathrm{CaHPO}_{4} \cdot 2 \mathrm{H}_{2} \mathrm{O}$. In earlier studies, the formation of $\mathrm{CaHPO}_{4}$ has been proposed [2], and in the system also with $\mathrm{H}_{3} \mathrm{PO}_{4}$, the formation of $\mathrm{CaF}_{2}$ has been found [13,14]. The results of the calculations with $1 \mathrm{M} \mathrm{HCl}$ are shown in Figures 1 and 2.

In Figure 1, the amounts (moles) of ions in aqua and solid phases in the case of $1 \mathrm{M} \mathrm{HCl}$ are presented depending on the amount of FAp added and on the solid-phase composition assumed. At the stoichiometric point (maximum of phosphorus dissolved) the aqua phase contains $\mathrm{Ca}^{2+}, \mathrm{H}^{+}, \mathrm{Cl}^{-}, \mathrm{H}_{2} \mathrm{PO}_{4}{ }^{-}$ions and $\mathrm{H}_{3} \mathrm{PO}_{4}$ and $\mathrm{CaCl}_{2}$ aqua complexes. The latter is formed in the amount below $0.15 \mathrm{~mol}$ that is not visible in a figure. The amount of $\mathrm{HCl}$ needed for the dissolution of 1 mole of FAp is 8.7 (HsC1) or 9.0 moles ( $\mathrm{HsC} 2)$.

The amount of $\mathrm{HCl}$ needed for the dissolution of 1 mole of FAp (and later the acid dose) changes from 7.6 to $8.8(\mathrm{HsC} 1)$ or $9.2(\mathrm{HsC} 2)$ according to the increase in $\mathrm{HCl}$ concentration from 0.05 to $2 \mathrm{M}$ (Figure 2) and the selected reaction products. This phenomenon can be explained by the change in $\mathrm{H}^{+}$consumption depending on the equilibrium of $\mathrm{H}_{3} \mathrm{PO}_{4}$ and $\mathrm{HPO}_{4}{ }^{2-}$ species in solution. 


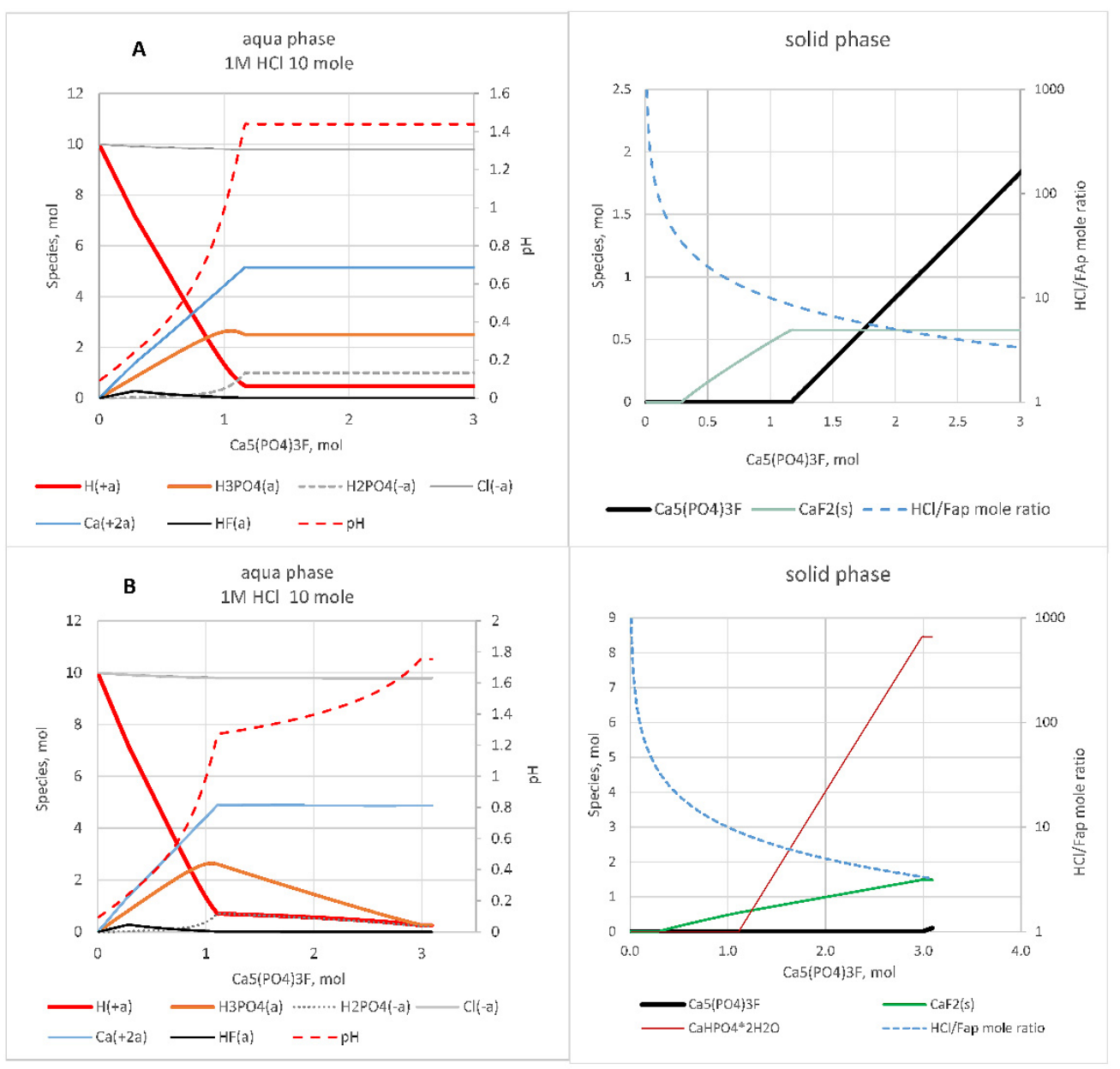

Figure 1. Aqua and solid-phase composition: 10 moles of $1 \mathrm{M} \mathrm{HCl}+\mathrm{FAp}$ : (A) $\mathrm{CaF}_{2}$ in the solid phase; (B) $\mathrm{CaF}_{2}$ and $\mathrm{CaHPO}_{4} \cdot 2 \mathrm{H}_{2} \mathrm{O}$ in the solid phase.

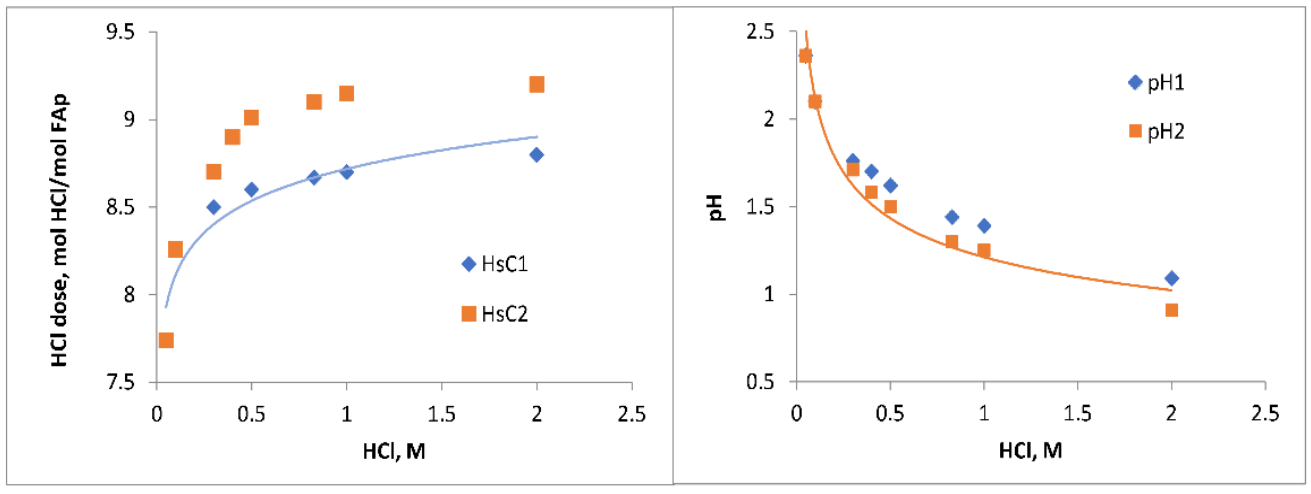

Figure 2. $\mathrm{HCl}$ amount needed for dissolution of 1 mole of $\mathrm{FAp}(\mathrm{HCl}$ dose) and $\mathrm{pH}$ depending on $\mathrm{HCl}$ concentration: $\mathrm{HsCl}$ - with $\mathrm{CaF}_{2} ; \mathrm{HsC} 2$ - with $\mathrm{CaF}_{2}$, and $\mathrm{CaHPO}_{4} \cdot 2 \mathrm{H}_{2} \mathrm{O}$.

The formation of $\mathrm{CaF}_{2}$ takes place at any $\mathrm{HCl}$ concentration. $\mathrm{CaHPO}_{4} \cdot 2 \mathrm{H}_{2} \mathrm{O}$ formation is possible at $\mathrm{HCl}$ concentrations above $0.2 \mathrm{M}$. In Figure 2 it is seen that at $\mathrm{HCl}$ concentrations above $0.2 \mathrm{M}$ and in the case of $\mathrm{CaF}_{2}$ formation alone, the dose of $\mathrm{HCl}$ is $0.4-0.5$ moles lower than in the case of simultaneous formation of $\mathrm{CaHPO}_{4} \cdot 2 \mathrm{H}_{2} \mathrm{O}$ and $\mathrm{CaF}_{2}$.

The $\mathrm{pH}$ value differs slightly depending on the solid phase formed (Figure 2) as the amount of $\mathrm{CaHPO}_{4} \cdot 2 \mathrm{H}_{2} \mathrm{O}$ is small. According to the calculations, $\mathrm{pH}$ increases in correlation with the quantity of apatite dissolved (Figure 1). In real conditions, the amount 
of apatite dissolved increases with time, and therefore, it could be described by the change of $\mathrm{pH}$.

\subsection{Experiments with Synthetic FAp}

The experiments of FAp dissolution in $\mathrm{HCl}$ at different concentrations and doses $(\mathrm{HCl} / \mathrm{FAp}$ mole ratio) were performed under the conditions described in Table 1. The minimum time used was limited by the very fine solid phase separation conditions. The $\mathrm{pH}$ value, $\mathrm{Ca}, \mathrm{P}$, and $\mathrm{F}$ content in the solutions were compared with the $\mathrm{HsC}$ calculations. $\mathrm{pH}$ measurements of the $\mathrm{HCl}$ solution mixtures with synthetic FAp revealed that the $\mathrm{pH}$ change is very fast and the speed increases with the increase in acid concentration (Figure 3). The value of $\mathrm{pH}$ stabilizes at $3000 \mathrm{~s}$ in $0.05 \mathrm{M} \mathrm{HCl}$ but in $0.5 \mathrm{M}$ solution only $1000 \mathrm{~s}$ is needed for stabilization, and in $1 \mathrm{M}$ solution even 600-700 s. These results are in accordance with the thermochemical measurements performed in $3 \%(1 \mathrm{M}) \mathrm{HCl}$ with synthetic apatites described in $[9,12]$.

Table 1. $\mathrm{pH}$ and solubility of $\mathrm{P}_{2} \mathrm{O}_{5}, \mathrm{CaO}$, and $\mathrm{F}$ in the experiments and by calculations.

\begin{tabular}{|c|c|c|c|c|c|c|c|}
\hline \multirow{2}{*}{ Exp. No. } & \multirow{2}{*}{$\begin{array}{l}\text { Calculation Mode } \\
\text { or Exp. Time }\end{array}$} & \multirow{2}{*}{$\begin{array}{l}\text { HCl Dose by HsC } \\
\text { Calculation, mol }\end{array}$} & \multirow{2}{*}{ HCl/FAp Mole Ratio } & \multirow{2}{*}{$\mathrm{pH}$} & \multicolumn{3}{|c|}{ Solubility, \% } \\
\hline & & & & & $\mathrm{P}_{2} \mathrm{O}_{5}$ & $\mathrm{CaO}$ & $\mathbf{F}$ \\
\hline \multicolumn{8}{|c|}{$\mathrm{HCl}$ Concentration $0.05 \mathrm{M}$} \\
\hline \multirow{4}{*}{1} & & 7.94 & & & & & \\
\hline & $\mathrm{HsC}$ & & 12.42 & 1.87 & 100 & 93.4 & 32.8 \\
\hline & $5 \mathrm{~h}$ & & 12.42 & 1.90 & 100 & 95.6 & 95.97 \\
\hline & $\mathrm{HsC}$ & & 10.24 & 2.01 & 100 & 92.4 & 37.90 \\
\hline \multirow[t]{4}{*}{2} & $5 \mathrm{~h}$ & & 10.24 & 2.08 & 100 & 98.2 & 83.86 \\
\hline & & $\mathrm{HC}$ & acentration $0.1 \mathrm{M}$ & & & & \\
\hline & & 8.26 & & & & & \\
\hline & $\mathrm{HsC}$ & & 10.2 & 1.82 & 100 & 91.4 & 13.5 \\
\hline \multirow[t]{3}{*}{5} & $5 \mathrm{~h}$ & & 10.20 & 1.79 & 99.40 & 98.5 & 26.22 \\
\hline & 3.5 months $^{\text {a }}$ & & & - & - & 98.2 & 24.21 \\
\hline & $\mathrm{HsC}$ & & 8.62 & 2.02 & 100 & 90.3 & 5.30 \\
\hline \multirow[t]{5}{*}{6} & $5 \mathrm{~h}$ & & 8.62 & 1.95 & 99.71 & 97.5 & 12.10 \\
\hline & & $\mathrm{HC}$ & acentration $0.5 \mathrm{M}$ & & & & \\
\hline & $\mathrm{HsC} 1$ & 8.55 & & & & & \\
\hline & $\mathrm{HsC} 2$ & 9.01 & & & & & \\
\hline & $\mathrm{HsC}$ & & 12.98 & 0.95 & 100 & 91.4 & 14.10 \\
\hline \multirow[t]{3}{*}{7} & $5 \mathrm{~h}$ & & 12.98 & 0.98 & 100 & 93.1 & 17.86 \\
\hline & HsC 1 & & 9.99 & 1.25 & 100 & 90.5 & 5.30 \\
\hline & HsC 2 & & 9.99 & 1.30 & 100 & 90.5 & 4.50 \\
\hline \multirow[t]{4}{*}{8} & $5 \mathrm{~h}$ & & 9.99 & 1.17 & 100 & 92.8 & \\
\hline & 3.5 months ${ }^{a}$ & & & - & - & $100 \pm 2$ & 17.00 \\
\hline & HsC 1 & & 6.47 & 1.65 & 77.4 & 70.0 & 1.35 \\
\hline & HsC 2 & & 6.47 & 1.60 & 60.9 & 66.7 & 1.55 \\
\hline \multirow[t]{6}{*}{9} & $5 \mathrm{~h}$ & & & 1.85 & 99.42 & - & 0.86 \\
\hline & & $\mathrm{HC}$ & centration $0.83 \mathrm{M}$ & & & & \\
\hline & $\mathrm{HsC} 1$ & 8.7 & & & & & \\
\hline & HsC 2 & 9.01 & & & & & \\
\hline & HsC 1 & & 8.24 & 1.48 & 96.5 & 87.0 & 1.24 \\
\hline & HsC 2 & & 8.24 & 1.34 & 88.1 & 83.0 & 1.71 \\
\hline \multirow[t]{5}{*}{10} & $24+72 \mathrm{~h}^{\mathrm{a}}$ & & 8.24 & 1.25 & 96.62 & 88.3 & 16.71 \\
\hline & & & ncentration $1 \mathrm{M}$ & & & & \\
\hline & $\mathrm{HsC} 1$ & 8.7 & & & & & \\
\hline & HsC 2 & 9.01 & & & & & \\
\hline & $\mathrm{HsC} 1$ & & 10.21 & 0.92 & 100 & 90.4 & 4.50 \\
\hline \multirow[t]{3}{*}{11} & $60 \mathrm{~min}$ & & 10.21 & 0.72 & 95.24 & 92.1 & 29.11 \\
\hline & HsC 1 & & 8.71 & 1.39 & 100 & 90.1 & 1.3 \\
\hline & HsC 2 & & 8.71 & 1.28 & 94.80 & 87.0 & 1.67 \\
\hline 12 & $5+45 h^{a}$ & & 8.71 & 1.09 & $100 \pm 2$ & 97.6 & 11.53 \\
\hline
\end{tabular}

${ }^{\mathrm{a}}$ storage time without mixing. 


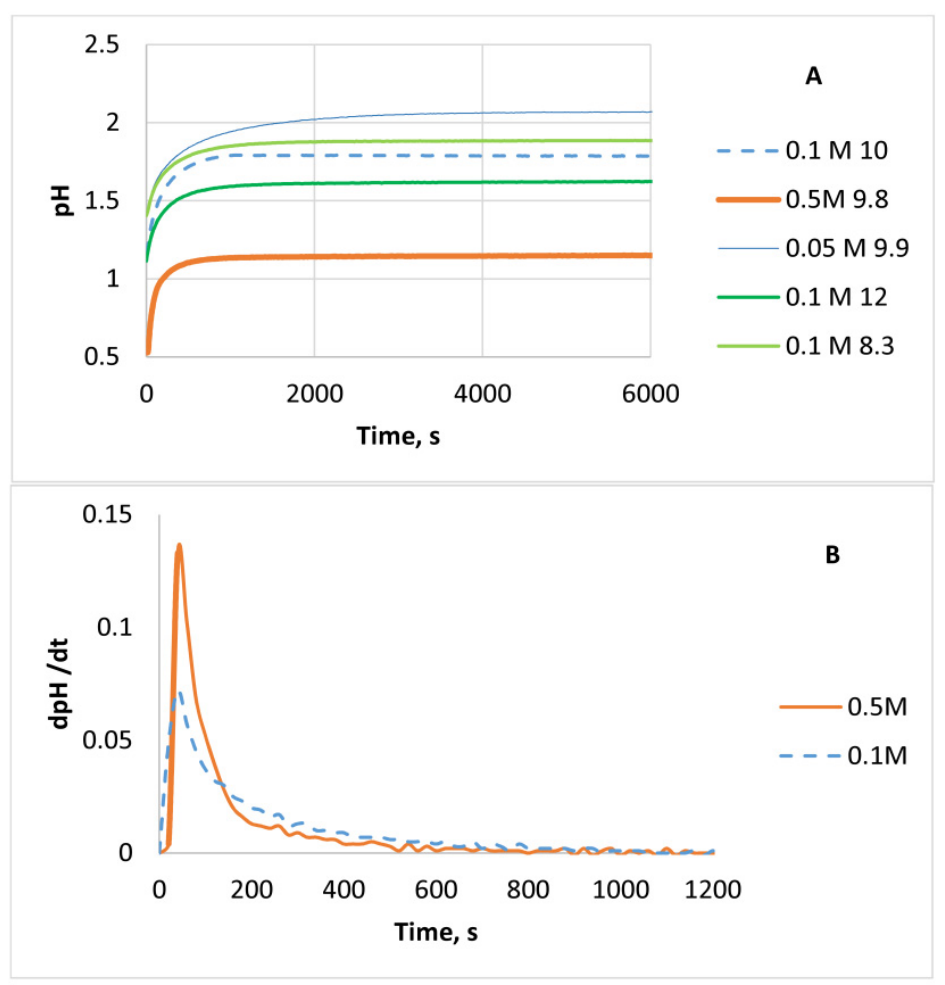

Figure 3. $\mathrm{pH}(\mathbf{A})$ and $\mathrm{dpH} / \mathrm{dt}(\mathbf{B})$ depending on time and $\mathrm{HCl}$ concentration.

The $\mathrm{pH}$ values measured in the experiments at longer times are closer to the calculated values and, at that, even closer in less-concentrated solutions (Table 1). The latter can be explained by the lack of precision of activity values in the calculations of strong acids. Additionally, the adsorption processes at solid surfaces are not taken into account in the equilibrium calculations that could slightly change the hydrogen ion consumption profile and rate in real experiments.

The solubility of F and Ca determined in the experiments is higher than calculated, but these values decrease with time. The difference is bigger for diluted $\mathrm{HCl}$ solutions (0.05-0.1 M) and in the case of $\mathrm{HCl}$ doses above stoichiometric. Solubility of $\mathrm{Ca}$ and $\mathrm{F}$ is lower than calculated if the dose of $\mathrm{HCl}$ is below stoichiometric, but $\mathrm{P}$ solubility is higher, which indicates the formation of the secondary solid phase $\mathrm{CaF}_{2}$. Therefore, the composition of the soluble part is affected not only by the acid concentration and time but also by the acid dose.

The XRD analysis of the solid phase separated after the reaction approved the formation of $\mathrm{CaF}_{2}$ (Table 2, Figure 4). In the case of an $\mathrm{HCl}$ dose above 10, the solid phase consisted only of $\mathrm{CaF}_{2}$. In the experiments at an almost stoichiometric amount of $\mathrm{HCl}$ (exp. 10 and 12), some amorphous phase is also detected in the solid part that, according to FTIR analysis, could be attributed to hydrogen phosphate. In Figure 5, the absorption bands at 1140,1074 , and $928 \mathrm{~cm}^{-1}$, characteristic of $\mathrm{H}-\mathrm{PO}_{4}$ vibrations [15], are seen. At the same time, the absorption bands of $\mathrm{PO}_{4}$ in FAp at 1089, 1018, and $603 \mathrm{~cm}^{-1}$ have been shifted or disappeared.

In the experiments with $\mathrm{HCl} / \mathrm{FAp}=6.5$ (below stoichiometric), the solid phase consisted of unreacted FAp and $\mathrm{CaF}_{2}$ (Table 2). The amount of $\mathrm{CaF}_{2}$ increased with time. 
Table 2. Solid phase composition in the reaction of FAp with $\mathrm{HCl}$ by XRD analysis.

\begin{tabular}{|c|c|c|c|c|c|c|}
\hline \multirow{2}{*}{ Exp. No. } & \multirow{2}{*}{ Exp. Time } & \multirow{2}{*}{$\mathrm{HCl}$ Conc., $\mathrm{M}$} & \multirow{2}{*}{$\begin{array}{l}\text { HCl/FAp } \\
\text { Mole Ratio }\end{array}$} & \multicolumn{3}{|c|}{ Solid Phase Composition, $\%$} \\
\hline & & & & $\mathrm{CaF}_{2}$ & FAp & $\mathrm{CaHPO}_{4}$ \\
\hline 5 & $5 \mathrm{~h}+3.5$ months $^{\mathrm{a}}$ & 0.10 & 10.20 & 100 & 0 & 0 \\
\hline \multirow[t]{3}{*}{8} & $5 \mathrm{~h}+3.5$ months ${ }^{a}$ & 0.50 & 9.99 & 98 & nd & 0 \\
\hline & $10 \min ^{\mathrm{b}}$ & 0.50 & 6.47 & 6.7 & 93 & nd \\
\hline & $60 \mathrm{~min}$ & 0.50 & 6.47 & 8 & 92 & nd \\
\hline \multirow[t]{3}{*}{9} & $300 \mathrm{~min}$ & 0.50 & 6.47 & 8 & 92 & nd \\
\hline & $24 \mathrm{~h}$ & 0.50 & 6.47 & 22 & 74 & 4 \\
\hline & $72 \mathrm{~h}$ & 0.50 & 6.47 & 19 & 81 & nd \\
\hline 10 & $24+72 \min ^{a}$ & 0.83 & 8.24 & & & FTIR \\
\hline \multirow[t]{3}{*}{11} & $10 \min ^{b}$ & 1.00 & 10.21 & 11 & 89 & nd \\
\hline & $10 \min ^{b}$ & 1.00 & 6.50 & 15 & 80 & 2 \\
\hline & $60 \mathrm{~min}$ & 1.00 & 6.50 & 11 & 83 & 7 \\
\hline \multirow[t]{3}{*}{13} & $300 \mathrm{~min}$ & 1.00 & 6.50 & 11 & 88 & 1 \\
\hline & $24 \mathrm{~h}$ & 1.00 & 6.50 & 28 & 72 & 1 \\
\hline & $72 \mathrm{~h}$ & 1.00 & 6.50 & 35 & 58 & 7 \\
\hline 12 & $5+45 h^{a}$ & 1.00 & 8.71 & 23 & 77 & FTIR \\
\hline
\end{tabular}

a storage time without mixing; ${ }^{\mathrm{b}}$ here filtration time exceeded the mixing time.

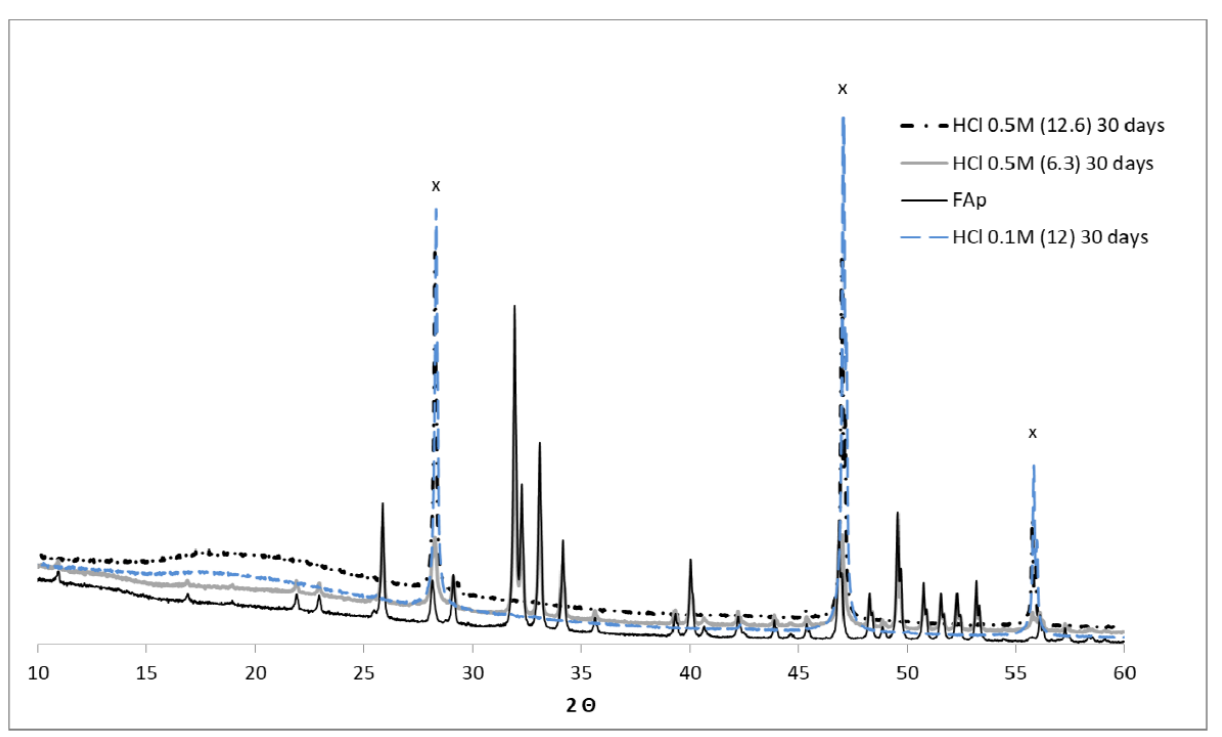

Figure 4. XRD patterns of FAp and solid residues after 30 days in the experiments with $0.1 \mathrm{M} \mathrm{HCl}$ (dose 12) and $0.5 \mathrm{M} \mathrm{HCl}$ (dose 12.6 and 6.3). $\mathrm{x}-\mathrm{CaF}_{2}$ (ICDD DB card nr 00-004-0864).

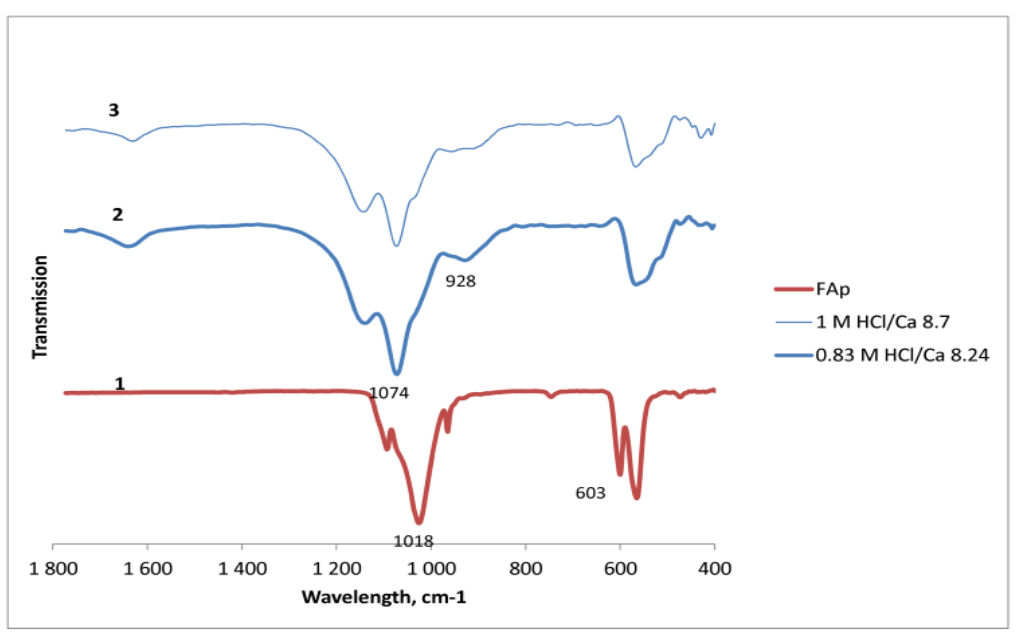

Figure 5. FTIR spectra of 1-FAp; 2-solid residue of experiment 10 ( $\mathrm{HCl} 0.83 \mathrm{M})$; 3-solid residue of exp. 12 ( $\mathrm{HCl} 1 \mathrm{M})$. 
As a result of the experiments, the formation of $\mathrm{CaF}_{2}$ was proved. Speed of $\mathrm{CaF}_{2}$ crystallization depends on $\mathrm{HCl}$ concentration and dose, being higher at lower acid dose and higher concentration (Table 2). $\mathrm{CaF}_{2}$ was found in the $\mathrm{HCl}$ solutions of $0.1 \mathrm{M}$ only after some months, whilst in the experiments with $1 \mathrm{M} \mathrm{HCl}$, it was found after only $10 \mathrm{~min}$. In the reactions describing the dissolution of FAp in $\mathrm{HCl}$ discussed in [1-6], the formation of $\mathrm{CaF}_{2}$ is not mentioned, but it is mentioned in the studies with $\mathrm{H}_{3} \mathrm{PO}_{4}[13,14]$. Possibly, $\mathrm{CaF}_{2}$ is not found in weak acid as the formation of it is much slower than FAp dissolution, but it occurs with remarkable speed at $\mathrm{HCl}$ concentrations of $5-25 \%$ used in the real phosphate rock treatment technology.

Crystalline $\mathrm{CaHPO}_{4} \cdot 2 \mathrm{H}_{2} \mathrm{O}$ was not detected, but a transition phase containing Ca$\mathrm{HPO}_{4}$ groups was present in the mixtures with a stoichiometric dose of $\mathrm{HCl}$, as was proposed by Dorozkin [2]. It was also not noticed in previous studies in which the $\mathrm{HCl}$ dose exceeded the stoichiometric dose, because in these conditions $\mathrm{CaHPO}_{4}$ dissolves.

Thus, by the information given above, it was shown that the proposed earlier net reaction for FAp dissolution in acids is a simplified description of the process.

\subsection{Kinetic Analysis}

According to $\mathrm{HsC}$ equilibrium calculations where apatite reacts with $1 \mathrm{M} \mathrm{HCl}$ solution (amounts of species less than two orders of magnitudes are eliminated), the dissolution process at the stoichiometric point of apatite dissolution can be described by the following equation:

$$
2 \mathrm{Ca}_{5}\left(\mathrm{PO}_{4}\right)_{3} \mathrm{~F}+17 \mathrm{H}^{+}+17 \mathrm{Cl}^{-} \rightarrow 2 \mathrm{~F}^{-}+10 \mathrm{Ca}^{2+}+17 \mathrm{Cl}^{-}+0.5 \mathrm{H}^{+}+6 \mathrm{H}_{2.75}\left(\mathrm{PO}_{4}\right)^{0.25-}
$$

with

$$
6 \mathrm{H}_{2.75}\left(\mathrm{PO}_{4}\right)^{0.25-}=4.5 \mathrm{H}_{3} \mathrm{PO}_{4}+1.5 \mathrm{H}_{2} \mathrm{PO}_{4}^{-}
$$

The reactions above fulfill the elements and charge balances. It is also assumed that new solid compounds $\mathrm{CaF}_{2}$ and $\mathrm{CaHPO}_{4}$, presented in the paper earlier, are formed slowly, and that in the initial stage only apatite dissolution Reaction (7) occurs.

For the batch reactor, the change in the total number of $\mathrm{H}^{+}$-ions $n_{\mathrm{H}+}$ can be expressed as:

$$
\begin{gathered}
\frac{d n_{\mathrm{H}^{+}}}{d t}=r_{\mathrm{H}^{+}} V, \\
\frac{d\left(V M_{\mathrm{H}^{+}}\right)}{d t}=r_{\mathrm{H}^{+}} V,
\end{gathered}
$$

giving

$$
\frac{d M_{\mathrm{H}^{+}}}{d t}=r_{\mathrm{H}^{+}},
$$

where

$r_{\mathrm{H}^{+}}$- consumption rate of $\mathrm{H}^{+}$ions, $\mathrm{mol} \mathrm{s}^{-1} \mathrm{~L}^{-1}$

$V$-solution volume, $\mathrm{L}$

$\mathrm{M}_{\mathrm{H}^{+}}$- molar concentration of hydrogen ions, $\mathrm{mol} \mathrm{L}^{-1}$

and according to Reaction (7), the reaction rates for apatite dissolution and ions formed are $\frac{d M_{\mathrm{FAp}}}{d t}=r_{\mathrm{FAp}}=\frac{2}{17} r_{\mathrm{H}^{+}}, \frac{d M_{\mathrm{Ca}^{2+}}}{d t}=r_{\mathrm{Ca}^{2+}}=\frac{10}{17} r_{\mathrm{H}^{+}}, \frac{d M_{\mathrm{F}}}{d t}=r_{\mathrm{F}^{-}}=-\frac{2}{17} r_{\mathrm{H}^{+}}$, and $\frac{d M_{\mathrm{H}_{2.75}\left(\mathrm{PO}_{4}\right)^{0.25-}}}{d t}=r_{\mathrm{H}_{2.75}\left(\mathrm{PO}_{4}\right)^{0.25-}}=-\frac{6}{17} r_{\mathrm{H}^{+}}$.

Here, the apatite (single solid phase) dissolution reaction rate is calculated in $\mathrm{mol} \mathrm{s}^{-1} \mathrm{~L}^{-1}$, and later its concentrations are calculated as $\mathrm{mol} \mathrm{L}^{-1}$. From the experimental data and calculations, it can be shown that the $\mathrm{pH}$ value of the solution is suitable for the description of the kinetics of the apatite dissolution process.

The $\mathrm{pH}$ change from the experiment with $1 \mathrm{M} \mathrm{HCl}$ solution (dose $8.7 \mathrm{~mol} \mathrm{HCl} / 1 \mathrm{~mol}$ apatite) is presented in Figure 3. In the calculations, the averaged datapoint values were used. The initial amount of apatite was $1.39 \mathrm{mmols}$, liquid volume was equal with the added $1 \mathrm{M} \mathrm{HCl}$ volume, $12.35 \mathrm{~mL}$, and the temperature was $25^{\circ} \mathrm{C}$. 
The exact concentrations of $\mathrm{H}^{+}$ions can be calculated from the $\mathrm{pH}$ values knowing the activity coefficient $\gamma_{\mathrm{H}}{ }^{+}$. On the basis of $\mathrm{HsC}$ calculations, the molar activity coefficient values are related to $\mathrm{pH}$ by the following equation $(\mathrm{R}=0.99)$

$$
\gamma_{\mathrm{H}^{+}}=0.843-0.032 \mathrm{pH}
$$

and from the definition of $\mathrm{pH}$

$$
\mathrm{pH}=-\log \left(\gamma_{\mathrm{H}^{+}} M_{\mathrm{H}^{+}}\right)
$$

the more exact molar concentration of hydrogen ions is then expressed as

$$
M_{\mathrm{H}^{+}}=10^{-\mathrm{pH}-\log \left(\gamma_{\mathrm{H}^{+}}\right)}
$$

The time-change of the molar concentration of $\mathrm{H}^{+}$ions in the time interval from $10 \mathrm{~s}$ to $820 \mathrm{~s}$ was fitted with numerous different functions and the mathematically most appropriate (regression coefficient $\mathrm{R}=0.99$ ) was found to be

$$
\ln \left(M_{\mathrm{H}^{+}}\right)=a+b \ln (t)+c[\ln (t)]^{2}
$$

with $a=1.94 ; b=-1.131 ; c=0.076$.

In this experiment, after $820 \mathrm{~s}$, the $\mathrm{pH}$ remains constant. From Equation (15), the molar concentration of $\mathrm{H}^{+}$ions at any time moment $t$ is

$$
M_{\mathrm{H}^{+}}=\exp \left\{a+b \ln (t)+c[\ln (t)]^{2}\right\}
$$

The consumption rate of $\mathrm{H}^{+}$ions can now be given as

$$
r_{\mathrm{H}^{+}}=\frac{d M_{\mathrm{H}^{+}}}{d t}=\left(\exp \left\{a+b \ln (t)+c[\ln (t)]^{2}\right\}\right)\left(\frac{b}{t}+2 c \frac{\ln (t)}{t}\right)
$$

Using the Relationship (11) the dissolution rate of apatite and the concentrations of $\mathrm{H}^{+}$ and other ions $\left(\mathrm{Ca}^{2+}, \mathrm{F}^{-}, \mathrm{H}_{2.75}\left(\mathrm{PO}_{4}\right)^{0.25-}\right)$ can now be calculated by solving the ordinary differential equation system (Equations (10) and (11)). The initial conditions are: $t=0 \mathrm{~s}$ : $M_{\mathrm{H}+}=1.186, M_{\mathrm{FAp}}=0.113, M_{\mathrm{Ca} 2+}=0, M_{\mathrm{F}}{ }^{-}=0, M_{\mathrm{H}_{2.75}(\mathrm{PO} 4)}=0(\mathrm{~mol} / \mathrm{L})$. The very first seconds are excluded as not suitable for Equation (15). The first period of dissolution, until $300 \mathrm{~s}$, is used for the graphical illustration of the calculation results, shown in Figure 6.

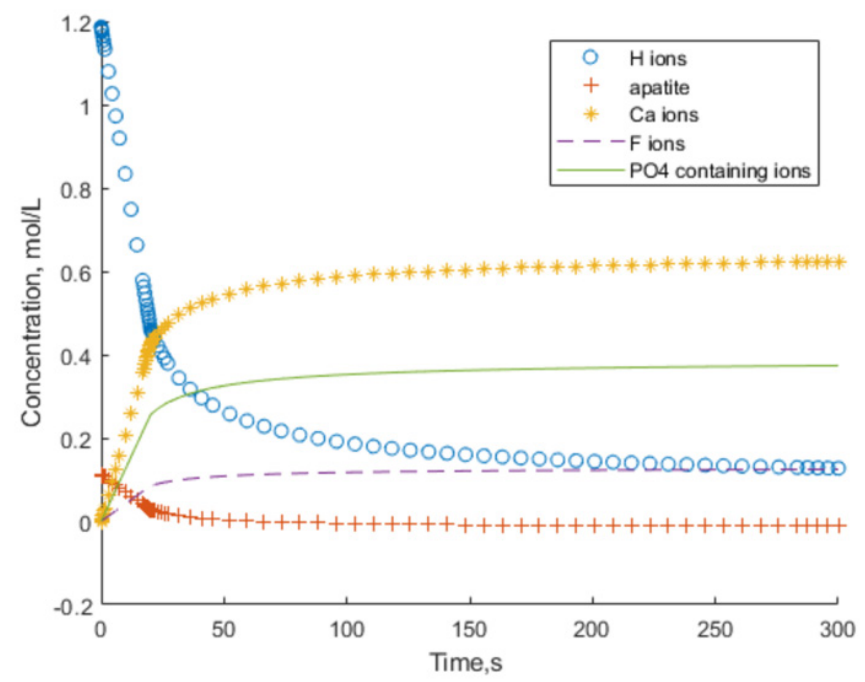

Figure 6. Batch experiment simulation. 
The other parameters of the solution ( $\mathrm{P}, \mathrm{Ca}$, and $\mathrm{F}$ concentrations) are affected by the secondary reactions of the formation of $\mathrm{CaF}_{2}$ and $\mathrm{CaHPO}_{4}$, and therefore, the only comparable parameter to describe the FAp dissolution kinetics in calculations and experiments is $\mathrm{pH}$.

\section{Materials and Methods}

FAp was synthesized by precipitation from aqueous solution. Two solutions-one containing $\mathrm{Ca}\left(\mathrm{NO}_{3}\right)_{2}(0.5 \mathrm{M})$, the other containing $\left(\mathrm{NH}_{4}\right)_{2} \mathrm{HPO}_{4}(0.6 \mathrm{M})$ and $\mathrm{NH}_{4} \mathrm{~F}(0.2 \mathrm{M})-$ were added simultaneously to $\mathrm{NH}_{4} \mathrm{OH}-\mathrm{NH}_{4} \mathrm{NO}_{3}$ solution under $\mathrm{N}_{2}$ flow and $80{ }^{\circ} \mathrm{C}$ temperature. The $\mathrm{pH}$ of the solution was adjusted and maintained at 9 . The precipitate was washed thoroughly with distilled water and dried after separation of the mother liquor and finally calcined at $800{ }^{\circ} \mathrm{C}$. The chemical composition of the FAp obtained was $\mathrm{P}_{2} \mathrm{O}_{5}$ 41.35, $\mathrm{CaO} 54.11$, and F $3.47 \%$. The FTIR and XRD spectra of the product corresponded to pure FAp (ICDD, DB card nr 00-060-0667). Ap unit cell parameters were $\mathrm{a}=9.3705(16)$ and $\mathrm{c}=6.8818(15) \AA$.

All reagents for synthesis and analyses were bought from ACROS organics (Acros Organics B.V.B.A., Fair Lawn, NJ, USA), Sigma-Aldrich (St. Louis, MO, USA), and Merck (Merck \& Co., Kenilworth, NJ, USA) and used as-bought.

The surface area of the FAp $\left(3.6 \mathrm{~m}^{2} \cdot \mathrm{g}^{-1}\right)$ was measured by the BET-method (adsorptive gas $\mathrm{N}_{2}$, carrier gas $\mathrm{He}$, heating temperature $150^{\circ} \mathrm{C}$ ) using a sorptometer KELVIN 1040/1042 (Costech International, Tallinn, Estonia).

In the batch experiments of the dissolution process, different amounts of FAp were added to the exactly measured amounts of $0.05,0.1,0.5$, and $1.0 \mathrm{M} \mathrm{HCl}$ solution and the suspension was mixed in an overhead mixture up to $72 \mathrm{~h}$ or by an automatic titrator that allowed to follow the change of $\mathrm{pH}$ in short time intervals up to $5 \mathrm{~h}$. After solid-phase separation, the composition of the solution was analyzed. The solid-phase composition was determined by XRD and FTIR spectroscopy.

pH was measured with Mettler Toledo electrode DG-117 Water, calibrated with Mettler Toledo $\mathrm{pH}$ buffer solutions $(2.0 ; 4.01 ; 7.00)$, and connected to a Mettler Toledo automatic titrator T90 (Greifensee, Switzerland) in the propeller-mixed suspension every $20 \mathrm{~s}$. In the solutions after solid-part separation by filtration, the concentration of $\mathrm{Ca}^{2+}$ ions was determined by atomic absorption spectrometry (Spectra AA 55B, Varian BV, Varian Australia Pty Ltd., Belrose, Australia) and the concentration of phosphorus was determined spectrophotometrically (Biochrom Libra S70PC, Cambridge, UK) as the phosphomolybdate yellow complex $(\lambda=430 \mathrm{~nm})$. The fluoride concentration in the solution was determined by an F-selective electrode (Mettler Toledo, Greifensee, Switzerland).

XRD patterns were obtained with a difractometer Rigaku Ultima IV, Wilmington, MA, USA ( $40 \mathrm{kV}, 40 \mathrm{~mA}$, scan speed $5 \mathrm{deg} \mathrm{min}^{-1}$, step $0.0200 \mathrm{deg}$, K-beta filter). The cell dimensions were determined by Rigaku PDXL 2 software.

FTIR spectra were recorded with a Bruker 55/S/NIR FTIR ATR spectrometer (Bremen, Germany) as an average of 32 scans at a resolution of $4 \mathrm{~cm}^{-1}$.

\section{Computational Methods}

An equilibrium composition was calculated using HSC Chemistry ${ }^{\circledR}$ software version 10.0.1.8 (Outotec, Finland) which uses the Gibbs energy minimization method. The input species for calculations are given in Table 3, their thermochemical data was taken from the program database.

In the simulations of the dissolution process, Matlab R2020b (update 4), MathWorks, Inc., Natick, MA, USA was used. 
Table 3. The input species for calculations of the equilibrium composition.

\begin{tabular}{cc}
\hline Phase & Formula \\
\hline Mixture & $\mathrm{N}_{2}(\mathrm{~g}) ; \mathrm{HCl}(\mathrm{g}) ; \mathrm{HF}(\mathrm{g})$ \\
& $\mathrm{H}_{2} \mathrm{O} ; \mathrm{OH}(-\mathrm{a}) ; \mathrm{HCl}(\mathrm{a}) ; \mathrm{Cl}(-\mathrm{a}) ; \mathrm{CaCl}_{2}(\mathrm{a}) ; \mathrm{F}(-\mathrm{a}) ; \mathrm{HF}(\mathrm{a}) ;$ \\
Aqua & $\mathrm{HPO}_{4}(-2 \mathrm{a}) ; \mathrm{H}_{3} \mathrm{PO}_{4}(\mathrm{a}) ; \mathrm{H}_{2} \mathrm{PO}_{4}(-\mathrm{a}) ; \mathrm{PO}_{4}(-3 \mathrm{a})$ \\
& $\mathrm{H}(+\mathrm{a}) ; \mathrm{Ca}(+2 \mathrm{a})$ \\
Pure solids & $\mathrm{Ca}_{5}\left(\mathrm{PO}_{4}\right)_{3} \mathrm{~F} ; \mathrm{CaF}_{2}(\mathrm{~s}) ; \mathrm{CaHPO}_{4} \cdot 2 \mathrm{H}_{2} \mathrm{O}$ \\
\hline
\end{tabular}

\section{Conclusions}

The correlation between the $\mathrm{pH}$ change and the apatite dissolution rate depending on $\mathrm{HCl}$ concentration was studied by thermodynamic calculations and experiments with synthetic fluorapatite.

A mathematical description of the studied dissolution process was composed, according to which the kinetics of dissolution can be determined by measuring the $\mathrm{pH}$ values of the system.

According to thermodynamics calculations, the stoichiometric amount of $\mathrm{HCl}$ needed for FAp dissolution depends on acid concentration. The experiments showed, as expected, that the dissolution of FAp is very fast and depends also on acid concentration.

The formation of secondary solid phases $\left(\mathrm{CaF}_{2}\right.$ and $\left.\mathrm{CaHPO}_{4}\right)$ in the $\mathrm{FAp}-\mathrm{HCl}$ system was proved and should be considered as a possible prerequisite for diffusion limitation at dissolution.

The reaction rate cannot be deduced from the calcium, fluorine, and phosphorus content of the solution as the secondary reactions of $\mathrm{CaF}_{2}$ and $\mathrm{CaHPO}_{4}$ formation (notably at higher acid concentration) take place simultaneously.

The next stage of the studies will involve natural apatites.

Author Contributions: Conceptualization, K.T., J.K. and R.K.; methodology, K.T., J.K.; validation, K.T., J.K.; formal analysis, K.T., G.H.-E.; investigation, K.T., G.H.-E., J.K.; writing-original draft preparation, K.T., J.K.; writing-review and editing, K.T., J.K. and R.K., G.H.-E., A.T.; visualization, K.T., G.H.-E.; supervision, A.T.; project administration, A.T.; funding acquisition, A.T. All authors have read and agreed to the published version of the manuscript.

Funding: This research was funded by the European Regional Development Fund and Estonian Research Council via project RESTA23.

Acknowledgments: This study was supported by the European Regional Development Fund and Estonian Research Council via project RESTA23. The authors thank K. Tamm for the help with HSC software.

Conflicts of Interest: The authors declare no conflict of interest.

\section{References}

1. Schorr, M.; Valdez-Salas, B.; Zlatev, R.; Stoytcheva, M. Phosphate ore processing for phosphoric acid production: Classical and novel technology. Miner. Process. Extr. Met. 2010, 119, 125-129. [CrossRef]

2. Dorozkin, S.V. Dissolution mechanism of calcium apatites in acids: A review of literature. World J. Methodol. 2012, 2, 1-17. [CrossRef]

3. Aly, H.F.; Ali, M.M.; Taha, M.H. Dissolution Kinetics of Western Deseret Phosphate Rocks, Abu Tartur with Hydrochloric Acid. Arab. J. Nucl. Sci. Appl. 2013, 46, 1-16.

4. Abd El-Mottaleb, M.; Cheira, M.F.; Gouda, G.A.H.; Ahmed, A.S.A. Leaching of Rare Earth Elements from Egyptian Western Desert Phosphate Rocks using HCl. Chem. Adv. Mat. 2016, 1, 33-40.

5. Kandil, A.-H.T.; Mira, H.I.; Mohamed, H.; Taha, M.H.; Kamel, M.F. Production of pure phosphoric acid from El-Sebaeya low-grade phosphate ore. Sep. Sci. Technol. 2017, 52, 679-690. [CrossRef]

6. Shlewit, H. Treatment of phosphate rocks with hydrochloric acid. J. Radioanal. Nucl. Chem. 2010, 287, 49-54. [CrossRef]

7. Stone, K.; Bandara, A.; Senanayake, G.; Jayasekera, S. Processing of rare earth phosphate concentrates: A comparative study of pre-leaching with perchloric, hydrochloric, nitric and phosphoric acids and deportment of minor/major elements. Hydrometallurgy 2016, 163, 137-147. [CrossRef] 
8. Zendah, H.; Khattech, I.; Jemal, M. Thermochemical and kinetic studies of the acid attack of "B" type carbonate fluorapatites at different temperatures (25-55) ${ }^{\circ} \mathrm{C}$. Thermochim. Acta 2013, 565, 46-51. [CrossRef]

9. Chihi, H.; Khattech, I.; Jemal, M. Thermochemistry and kinetics of the attack of magnesium-carbonate co-substituted fluo-rapatites by hydrochloric acid at different temperatures $(25-55){ }^{\circ} \mathrm{C}$. Thermochim. Acta 2016, 646, 16-25. [CrossRef]

10. Bandara, A.; Senanayake, G. Dissolution of calcium, phosphate, fluoride and rare earth elements (REEs) from a disc of natural fluorapatite mineral (FAP) in perchloric, hydrochloric, nitric, sulphuric and phosphoric acid solutions: A kinetic model and comparative batch leaching of major and minor elements from FAP and RE-FAP concentrate. Hydrometallurgy 2018, 184, 218-236. [CrossRef]

11. Wu, S.; Zhao, L.; Wang, L.; Huang, X.; Zhang, Y.; Feng, Z.; Cui, D. Simultaneous recovery of rare earth elements and phos-phorus from phosphate rock by phosphoric acid leaching and selective precipitation: Towards green process. J. Rare Earths 2019, 37, 652-658. [CrossRef]

12. Brahim, K.; Soussi-Baatout, A.; Khattech, I.; Jemal, M. Dissolution kinetics of fluorapatite in the hydrochloric acid solution. J. Therm. Anal. Calorim. 2017, 129, 701-708. [CrossRef]

13. Zendah, H.; Khattech, I.; Jemal, M. Synthesis, characterization, and thermochemistry of acid attack of "B" type carbonate fluorapatites. J. Therm. Anal. Calorim. 2012, 109, 855-861. [CrossRef]

14. Soltani, F.; Abdollahy, M.; Petersen, J.; Ram, R.; Koleini, S.J.; Moradkhani, D. Leaching and recovery of phosphate and rare earth elements from an iron-rich fluorapatite concentrate: Part II: Selective leaching of calcium and phosphate and acid baking of the residue. Hydrometallurgy 2018, 184, 29-38. [CrossRef]

15. Gadaleta, S.J.; Paschalis, E.P.; Betts, F.; Mendelsohn, R.; Boskey, A.L. Fourier transform infrared spectroscopy of the solu-tionmediated conversion of amorphous calcium phosphate to hydroxyapatite: New correlations between X-ray diffraction and infrared data. Calcif. Tissue Int. 1996, 58, 9-16. [CrossRef] [PubMed] 